\title{
A review of trends in the distribution of vector-borne diseases: is international trade contributing to their spread?
}

\author{
S. de La Rocque ${ }^{(1,2)}$, T. Balenghien (2), L. Halos ${ }^{(3)}$, K. Dietze ${ }^{(1)}$, \\ F. Claes ${ }^{(1,4,5)}, G$. Ferrari ${ }^{(1)}$, V. Guberti ${ }^{(1,6)} \&$ J. Slingenbergh ${ }^{(1)}$ \\ (1) Emergency Prevention Programme for Transboundary Animal Diseases, Food and Agriculture \\ Organization of the United Nations, Viale delle Terme de Caracalla, 00153, Rome, Italy \\ The views expressed in this article are those of the authors and do not necessarily reflect the views \\ of the Food and Agriculture Organization of the United Nations. Also, the designations employed and the \\ presentation of material in this information product do not imply the expression of opinion whatsoever \\ on the part of the Food and Agriculture Organization of the United Nations concerning the legal status of any \\ country, territory, city or area or of its authorities, or concerning the delimitation of its frontiers or boundaries. \\ Content and errors are exclusively the responsibility of the authors. \\ (2) Centre International de Recherche Agronomique pour le Développement, Unité Mixte de Recherche, \\ Contrôle des maladies animales exotiques et émergentes, Campus international de Baillarguet, \\ Montpellier, France \\ (3) Merial, 29 av. Tony Garnier, 69007 Lyons, France \\ (4) Institute of Tropical Medicine Antwerp, Department of Parasitology, Nationalestraat 155, \\ 2000 Antwerp, Belgium \\ (5) Katholieke Universiteit Leuven, Department of Biosystems, Kasteelpark Arenberg 30 , \\ 3001 Leuven, Belgium \\ (6) Instituto Superiore per la Protezione e la Ricerca Ambientale (ISPRA), Ozzano Emilia, Italy
}

\section{Summary}

It is difficult to determine the part that international trade has played in the expansion of vector-borne diseases, because of the multitude of factors that affect the transformation of habitats and the interfaces between vectors and hosts.

The introduction of pathogens through trade in live animals or products of animal origin, as well as the arrival of arthropod vectors, is probably quite frequent but the establishment of an efficient transmission system that develops into a disease outbreak remains the exception.

In this paper, based on well-documented examples, the authors review the ecological and epidemiological characteristics of vector-borne diseases that may have been affected in their spread and change of distribution by international trade. In addition, they provide a detailed analysis of the risks associated with specific trade routes and recent expansions of vector populations. Finally, the authors highlight the importance, as well as the challenges, of preventive surveillance and regulation. The need for improved monitoring of vector populations and a readiness to face unpredictable epidemiological events are also emphasised, since this will require rapid reaction, not least in the regulatory context.

\section{Keywords}

Animal - Animal product - Epidemiology - Risk - Spread - Trade Vector-borne disease.

\section{Introduction}

Throughout history, the opening up of travel and travel routes has been accompanied by biological invasions, including pests and diseases and their vectors (75). Perhaps the most devastating, invasive vector-borne disease - the plague (caused by the bacterium, Yersinia pestis) - was initially transmitted by the rat flea, Xenopsylla 
cheopis. Pandemics of bubonic plague probably killed onethird of the European population (39). Similarly, the introduction of yellow fever virus and its vector, Aedes aegypti, to the New World in the 17th Century caused mass mortality among native Amerindians and European settlers (78). Another example of a major vector-borne disease expansion was the disease spread that occurred after the introduction of the important African malaria mosquito vector, Anopheles gambiae, into north-eastern Brazil in the 1930s (56). One example of a non-arthropod vector is the flatworm Schistosoma mansoni, the agent of intestinal schistosomosis, which was introduced into the American tropics with its competent intermediate host, the snail, Biophalaria glabrata (42).

During the 20th Century, scientific advances in insect biology and ecology, as well as the new availability of highly effective pesticides (acaricides and insecticides, especially dichlorodiphenyltrichloroethan or DDT), parasiticides and vaccines contributed to what later turned out to be the mistaken belief that many vector-borne and infectious diseases belonged to the past (36). Indeed, impressive results were obtained in the control and elimination of some vector-borne diseases, including yellow fever and malaria, particularly in the temperate climate zones. However, most of these gains were at the perimeter of the global disease distributions, where the vector is more vulnerable and disruption of transmission more readily achieved.

Following the awakening of scientific interest and the positive early results of campaigns against diseases and vectors, interest in vector-borne diseases gradually decreased and many were catalogued more as tropical diseases persisting in remote areas (68). Wide-scale use of insecticides was gradually abandoned, and even banned, for ecological reasons, largely because of the negative effects of persistent insecticides on non-targeted species across trophic layers. In the absence of major vector-borne epidemics or epizootics in Europe, campaigns against mosquitoes were mainly focused on the seasonal nuisance that they caused (32). Moreover, formal training in medical entomology became neglected, to the extent that in France a warning was addressed to politicians (17).

Lately, and in particular since 2000, a series of outbreaks of vector-borne diseases in humans and animals in Europe and North America has put these diseases back at the top of the agenda. Interestingly, not just one type of pathogen or vector has emerged but a range of viruses, bacteria and parasites. These pathogens cause a range of diseases, including:

- mosquito-borne disease (West Nile fever, chikungunya and dengue)

- tick-borne disease (Lyme disease and tick-borne encephalitis)
- midge-borne disease (bluetongue, epizootic haemorrhagic disease, leishmaniosis)

- fly-borne disease (Old and New World screwworm, animal trypanosomosis) (63).

Climate change has been incriminated on the basis that the impact of abiotic factors on the distribution of arthropods is well recognised. However, while climate change is probably a contributing factor, other factors associated with globalisation and land use are more important (22).

One of the main results of globalisation is the explosive growth in the mobility of people and the exchange of goods, including biological items. Many of the physical or cultural barriers that, in the past, have prevented such exchanges, and thus disease dissemination, have been removed in recent decades. During the past 50 years, the annual growth in air traffic passengers has averaged 9\%, while the volume of shipping traffic has increased by about 30\% since 1993 (75). International trade in live animals and animal products offers opportunities for pathogens and vectors to be transported across oceans and continents. However, with the exception of a few documented examples, discussed below, the specific contribution of globalisation to disease emergence is inherently difficult to quantify. First, there is a multiplicity of routes of introduction, including active and passive dispersal of vectors, travel by infected human hosts, animal movements and migration, and transportation of goods. Ten years after the introduction of West Nile virus into the United States, it is still not clear whether the disease was introduced by infected vectors or birds (43). Secondly, biological invasions are multi-step processes, involving introduction, initial dispersal, establishment and spread. Since the dynamics and interactions between pathogen, host and vector are complex and influenced by ecological conditions acting at different geographical scales, vectorborne disease encroachment upon ecosystems and biotopes is notoriously difficult to unravel (62). Given the increase in trade, introductions of alien species are also on the rise. Nevertheless, probably most introduced pathogens or vectors fail to amplify and become established.

The successful introduction and establishment of a vectorborne disease in a new area depend on a number of prerequisites and stochastic variables. An introduction may entail:

- an infected competent vector in a new environment inhabited by a susceptible vertebrate host species

- an infected vertebrate host species in a new environment inhabited by competent vector(s)

- an infected, susceptible vertebrate host, together with a competent vector, in a new environment where both can 
develop viable populations or where alternative susceptible vertebrate host species and/or competent vector(s) are available.

Once introduced, the number of infected hosts may amplify, provided that the population sizes of both the competent vector and the susceptible vertebrate host are large enough, and the transmission rate adequate, to result in a local epidemic. The local epidemic may become extinct in a short time (West Nile virus in France and Italy in 2000), evolve into long-lasting epidemic waves (West Nile virus in the United States) or turn into a more localised endemic infection (West Nile virus in the Po Valley, Italy, from 2008 until the present).

The evolution of the disease complex towards sustained endemicity is possible in a situation where the environment supports a ratio of competent vectors to susceptible vertebrate hosts over a certain threshold.

To further assess the role of trade in disease introduction, it is worth examining history to learn from events that took place in the distant past (63). Today's perception of the management of vector-borne diseases has been much influenced by relatively recent successes and may not fully reflect the magnitude of the risks confronted. For example, many people think that mosquito-borne diseases require tropical conditions, but history suggests that many mosquito-borne diseases may have prevailed at northern latitudes, at least until relatively recently. For example, catastrophic yellow fever epidemics used to be common during the 19th Century in North America, as far north as New York and Boston, and in European ports, such as Cardiff and Dublin (61). Denmark and parts of Sweden experienced major malaria outbreaks until the 1860s. The reasons for the decline of malaria in western countries have been detailed by Reiter (59); namely, despite the existence of competent vectors (57), and thousands of introductions annually, by travellers carrying parasites, malaria rarely causes secondary cases because of rapid detection and treatment. This example illustrates once more that the entry of pathogens does not necessarily translate into persistence of the disease.

\section{Trade and travel define the new atlas of vector-borne diseases}

Over history, an increasing number of incursions and the spread of vector-borne diseases have resulted from regional or intercontinental trade in live animals and animal products, and this process has dramatically altered the disease atlas. As pointed out by Blancou and Chillaud (9), most of these animal movements followed human migration and cannot really be described as having been triggered by trade. Yellow fever, and its main vector, Ae. aegypti, is a well-known example of a complete vector system being successfully introduced into the New World during the slave trade. Aedes aegypti is highly anthropophilic and the mosquito populations were apparently able to survive and breed in the casks used for the shipboard storage of water, while feeding on readily available human hosts. 'With the slaves and the mosquitoes came the deadly yellow fever virus ... hence the yellow flag of quarantine' (59).

More recently, ehrlichiosis or heartwater is known to have been introduced to the Caribbean by cattle imported in 1830 from Senegal, infested by the tick Amblyomma variegatum (77). The long development period of each stage of the tick on the host, plus its capacity to adjust to the available hosts, probably helped the tick and infection to survive transportation and then become disseminated upon introduction into a new area. (Amblyomma variegatum, which is usually telotrophic, can become monotrophic, feeding on livestock in situations where wild hosts are rare [7].)

Similarly, equine haemoparasites (Babesia equi and B. caballi), endemic in most tropical areas, were introduced into the United States in 1959, by horses imported from South America carrying Dermacentor nitens. The same thing happened in Australia in 1976, with horses from Asia. Dermacentor nitens is a monotrophic tick, in that all its stages feed and develop on a single host, which makes transportation less hazardous (54). However, nowadays, the speed of air travel makes the inability of these vectors to survive weeks of transportation much less important.

\section{The key scenarios for establishment}

If the key question is more about the capacity to become established, rather than stochastic factors and opportunities to enter, which are many, then a deeper analysis of the epidemiology of these diseases is needed. However, demographic, environmental, social, technological and other changes in human ecology, including urbanisation, are reshaping the epidemiology of many diseases (47), and disease emergence is extremely difficult to anticipate as long as these drivers are poorly understood $(55,63)$. Furthermore, if we accept that the opportunities for introduction have apparently increased during the past few decades, it is likely that we are still in a transition period, and that many more invasions are now in progress or yet to come. Moreover, the continuing expansion of mosquito distribution, discussed below, indicates that an equilibrium has not yet been reached. 


\section{Pathogens associated with many species of vector}

Many arboviruses are not very specific in terms of vector species associations. The transmission of West Nile virus involves mainly avian hosts and ornithophilic mosquitoes, especially from the genus Culex, of which many species are highly or moderately competent. As a result of this diversity in vectors, West Nile virus is by far the most widely distributed arbovirus (38). The disease may be introduced into new areas through wild bird migrations; disease flare-up is mainly observed along migratory bird flyways linking tropical wintering areas to the northern breeding sites, especially in the deltas of Africa and Europe (14). During epidemics, outbreaks can be observed in apparently random locations, from wetlands to suburban areas (5). Viraemia in humans and horses is generally too low to infect mosquitoes and therefore the introduction of West Nile virus into new areas by infected humans or equids seems improbable (60). Two major hypotheses remain for the recent introduction of West Nile virus into the United States: (i) it came with infected mosquitoes in an aeroplane; (ii) it was introduced by an imported infected bird. The second is more probable. The genetic resemblance to a virus circulating a few months previously in Israel supports the hypothesis that it could have been introduced from that region $(43,48)$.

Another disease with a wide range of potential vectors is Rift Valley fever. The Rift Valley fever virus has historically been held responsible for widespread and devastating outbreaks in many parts of the African continent, extending as far as the Arabian Peninsula and Madagascar. No fewer than 38 arthropod species have been found to be infected in nature, of which at least 35 have shown vector competence under controlled conditions (28). Among the mosquito species alone, six genera are represented, namely:

- Mansonia

- Anopheles

- Coquillettidia

- Eretmapodites

- Culex

- Aedes.

Certain species belonging to the last two genera are considered to be major vectors $(46,50)$.

Rift Valley fever can develop into dramatic outbreaks when the abundance of vectors increases following sustained rainfall and flood conditions (21). Epidemics may also occur when viraemic animals are introduced into areas with a high density of mosquitoes, such as irrigation schemes. The 1977 to 1978 epidemic along the Nile and in the Nile Delta resulted in the unprecedented number of
200,000 human infections with at least 594 deaths $(1,49)$. The virus is thought to have been introduced from Sudan through trading in small ruminants, transported by boats across Lake Nasser (35), and then further disseminated along the Nile River, probably by animals transported by railroad (70). Exported livestock were also incriminated in the introduction of the disease from the Horn of Africa into south-west Saudi Arabia and the adjoining provinces of Yemen in 2000 (2). Interestingly, these virus strains proved to be genetically very similar to those isolated from the 1997 to 1998 outbreak in the Great Horn of Africa (72). It has been speculated that infection smouldered in the Arabian peninsula from 1998 until 2000, when sustained heavy rains and increased mosquito populations again precipitated an epidemic (73). If confirmed, this hypothesis will illustrate how complex the ecological dynamics behind disease emergence really are.

\section{Pathogens associated with a specific vector}

Some pathogens are specific to their competent vectors. Such is the case with the African horse sickness virus, transmitted by blood-feeding midges, especially Culicoides imicola. The disease occurs throughout the African continent, where it is endemic, from the subSaharan dry belt to parts of South Africa. Occasionally, it has been reported by countries in North Africa, where the vector is also present, extending as far as the Middle East and Spain (15).

While not always precisely documented, these incursions are presumably related to the trade in, and movement of, horses. Outbreaks in Egypt tend to flare up in the southern parts of Aswan and Qena provinces. In 1943, at least, horses imported from Sudan were clearly incriminated (9). The major outbreak which occurred in the Middle East in 1959 followed the illegal importation of horses from East Africa and resulted in the death of 300,000 equids (80).

Trade in wild equids has also been documented as a possible source of the introduction of African horse sickness and subsequent outbreaks. In 1987, African horse sickness virus was introduced to a safari park close to Madrid, Spain, following the importation of ten infected zebras from Namibia (44, 64). African horse sickness infection in zebras is usually subclinical, yet the viraemia can persist for up to 40 days post infection (10). Viraemia has even been reported to occur in the presence of circulating antibodies, possibly because of the close association of the virus with erythrocytes in invaginations of the blood cell membrane, as also observed in bluetongue virus $(13,80)$. Hence, zebra constitute a 'Trojan horse' for the introduction of African horse sickness virus into disease-free areas (6). 
For many years, C. imicola was considered the sole vector of African horse sickness in Africa (26), before other species were proven competent: C. bolitinos in southern Africa (51) and C. variipennis in the United States (11). Past occurrences of African horse sickness in the Mediterranean Basin had always been linked to the presence of C. imicola, until the 1987 to 1990 outbreaks in Spain and Portugal, when the virus was isolated from mixed pools of Culicoides species other than C. imicola, suggesting that other species might also become involved in the transmission of the disease in Europe (10).

Bluetongue, a midge-transmitted disease of ruminants, is very similar to African horse sickness in terms of aetiology and transmission. The disease recently showed unprecedented spread beyond its endemic areas in subSaharan Africa into the Maghreb. From there, it crossed the Mediterranean in a few weeks, vectored by C. imicola (76). Culicoides imicola has recently extended its range northwards into naive areas of Europe (52). Both the virus (serotypes 1, 2, 4, 9 and 16) and the insect have meanwhile become firmly established in the southern part of Europe. However, given the rapid progression of the virus beyond the C. imicola distribution area, a number of other vectors, possibly also of the genus Culicoides, are apparently involved in its transmission (23).

The existence of additional competent species was confirmed in 2006 when bluetongue virus serotype 8 emerged in the Netherlands, hundreds of kilometres north of the known northernmost limit of C. imicola $(29,76)$. Based on knowledge collected during previous introductions of bluetongue virus serotypes (30), several hypotheses emerged on the ways in which serotype 8 may have been introduced. These included:

- the legal or illegal importations of infected domestic or wild ruminants (69)

- the introduction of midge vectors by the wind (this was later strongly suspected as the source of introduction of the virus into the United Kingdom [40], however, for the first flare-up of serotype 8 in the Netherlands, the distance from endemic areas was probably further than could be realistically expected from windborne spread)

- the passive transport of Culicoides by aircraft

- the transport of vectors through international trade in containers of plants, especially flowers from endemic areas of Africa

- the introduction of an infected biological source, in particular, contaminated vaccines.

Although bluetongue virus has occasionally been detected in the semen of viraemic bulls, field studies of naturally infected bulls in both the United States and Australia indicate that transmission of field viruses by semen is extremely rare, if it happens at all. Experimental infection of bulls with laboratory-adapted strains of bluetongue virus has shown an intermittent presence of virus in semen during viraemia (41), possibly because of the presence of blood cells in the semen (12). Thorough investigation of shipments of domestic and wild ruminants, or semen or embryos, that occurred before the outbreak in the Netherlands did not reveal any likely source of virus and so the route of introduction remains unknown (53).

\section{Pathogens for which vector association is not strictly necessary}

African swine fever is endemic in the pig populations of most countries of sub-Saharan Africa and its epidemiology is relatively well understood. Where the infection is endemic, the transmission of the virus occurs mainly through the oro-nasal route, between domestic pigs and also wild boar or feral pigs. The long-distance spread of African swine fever results mainly from feeding pigs food waste that contains pork products contaminated with the virus. If competent vectors (Ornithodoros spp.) are present, they play an important role in the local transmission cycle of the virus; in particular, enhancing its persistence in an area.

In the African sylvatic cycle, the warthog (Phacochoerus) burrow biocenose, comprising all the warthog age classes and the Ornithodoros soft tick genus, plays the epidemiological role of virus reservoir. The warthog does not show any clinical signs and has life-long viraemia. However, titres are high for a limited period only, during which the virus is transmitted directly through the usual oro-nasal route. Outside this period of high-titre viraemia, only ticks can transmit the infection from an infected to a susceptible warthog. Ticks also play a key role in the transmission of the virus from the sylvatic habitat to domestic pigs.

The history of African swine fever's emergence in countries within and outside Africa has shown the disease to have quite different impacts, depending on:

- the presence of vectors

- the breed of pigs

- husbandry methods

- the ability of the pig production subsector and veterinary authorities to jointly implement effective control measures (reviewed in 16).

Nearly all African swine fever outbreaks outside Africa have been associated with formal or informal trade in pork and pork products $(33,45,65)$, and the feeding of pigs with food waste containing contaminated pork. In theory, the legal international trade in live animals could be a 
source of introduction, but it has presumably not yet played a role, and this is not likely to change, given that any substantial trade in live pigs involves commercial pig production units implementing effective disease prevention measures (31). The recent introduction and spread of African swine fever to the Caucasus suggest routes of introduction coinciding with the trade in pork products, both local and long distance. Hence, feeding pigs with food waste linked to informal trade unfortunately remains a main source of the propagation of African swine fever in Eastern Europe (34).

The increasing worldwide exchange of people and products presents opportunities for African swine fever to show up in naïve pig populations around the world. The impact of introduction is likely to be devastating in regions with high pig densities and also prominent extensive production systems, as found, for example, in southern China and parts of Southeast Asia. The enhanced support by China to selected African countries, in the areas of trade and development, has been identified as a risk for the first introduction of African swine fever into eastern Asia (8).

Trade regulations represent a tool to reduce risks of introduction. However, their effectiveness in disease prevention is challenged by widespread, informal trade links and travel by air, land or water. 'Harvest seasons', such as those associated with the Lunar New Year (also called the 'Chinese New Year'), or during the run-up to Orthodox Christmas in Eastern Europe, present high-risk moments for the introduction and spread of African swine fever, due to the increased trade of pork products at such times.

The likelihood of persistence of African swine fever virus in naive areas is difficult to assess, since it is not clear whether the disease can persist in the absence of a wildlife reservoir and tick vectors. Soft ticks are not easy to find, and information on their geographic distribution is scarce. Ornithodoros species have been encountered in the Americas, Africa, parts of Europe, the Caucasus and parts of Asia. There is no evidence to suggest that they play a role through international trade, since soft ticks do not remain on the vertebrate host beyond the time needed to feed on blood.

\section{Is it possible to determine the role of trade in the establishment of vector-borne diseases?}

Davies reviewed the introduction of Rift Valley fever to the Arabian Peninsula in 2000 and described some of the main factors favouring disease spread through livestock trade in this particular set of circumstances (19). The two major religious festivals in Mecca during Ramadan are Eid ul-Fitr and Eid ul-Adha/Arafa, attracting millions of pilgrims. The Eid ul-Adha festival, in particular, features the ritual sacrifice of a ram. To supply the demand, sheep are traded to Mecca from as far away as the pastoral areas in the Great Horn of Africa (north-east Kenya, Somalia, south-east Ethiopia, western Sudan and Yemen) (18, 20). The Somali black-head or fat-tailed sheep are highly prized for this ceremony. The trade in small ruminants during this period has been valued at US\$0.6 to US\$0.9 billion.

Two main systems prevail. The first involves the transport network of roads from regional markets in Somalia, Ethiopia or north Kenya, to the ports on the Red Sea (Berbera, Bossasso and Port Sudan), and from there by boat to Jeddah, Saudi Arabia. The second, more traditional system is one in which animals are exported from Africa to Yemen, mostly via the port of Mokkah, for fattening in the plateau and tihama zones of Yemen, before taking the traditional trade route northwards, leading from Yemen to Saudi Arabia.

In his review, Davies (18) examined the risk of the spread of Rift Valley fever from the Horn of Africa to the Middle East and observed that:

- by the time the virus is detected at the point of origin, it is usually too late to disrupt onward transmission as infected animals may already have been exported

- the trade routes involving the port of Jizan enable animals to arrive in Jeddah within five to ten days after leaving the markets of origin

- the journey by road and sea from the Horn of Africa to Jeddah may be completed within the incubation period of Rift Valley fever, which is one to seven days, and viraemia may persist for another one to seven days

- a $1.5 \%$ to $3 \%$ infection rate, which readily prevails when the animals are shipped from an area at the time of peak virus activity, would translate into a total of some 15,000 to 30,000 infected sheep being slaughtered on the peak day of Eid ul-Adha

- virus exposure through blood contact presents a major risk of transmission to humans through skin cuts, abrasions or from inhalation of blood aerosols when cutting throat arteries during slaughter.

\section{More to come?}

This discussion has illustrated the need for a detailed analysis of trade dynamics and systems to be blended into the epidemiology of the disease. However, such knowledge 
is challenged by the rapidly rising number of biological invasions, including those by disease vectors. For example, it has been shown that modern container ships redistribute numerous alien mosquito species, as with Ae. japonicus (66, 79) or the Asian tiger mosquitoes, Ae. albopictus (4). Aedes albopictus is vector-competent for at least 22 arboviruses, including those of dengue, yellow fever and West Nile fever (67). During the past three decades, the range of Ae. albopictus has expanded intercontinentally, principally through shipborne transportation of eggs and larvae in used automobile tyres (58). Its introduction has also been traced to imports of 'lucky bamboo' from sub-tropical Asia (67).

In a recent study, Tatem et al. (75) combined climatic information with data on international ship and aircraft traffic movements to map disease-vector suitability and accessibility areas, with a specific focus on Ae. albopictus. The analysis revealed that, in climatically similar ports, those areas where successful introduction and establishment had occurred had traffic volumes that were more than twice as high. Following establishment of the vector, the introduction of viraemic hosts may translate into local outbreaks. This was the case with the introduction of chikungunya virus into Italy in 2008, during the peak abundance of Ae. albopictus, resulting in hundreds of human cases (3). In 2010, the introduction of Ae. aegypti became evident in northern Europe, probably also through used tyres (27). This mosquito species is primarily an urban vector for dengue and yellow fever and was once established as far north in Europe as Brest and Odessa (60).

In their study on the tiger mosquito, Tatem et al. (75) highlighted the importance of routes originating from Eastern Asia (more specifically, Japan) to North America and Mediterranean Europe. Interceptions of Ae. albopictus in tyre shipments from Japan to Australasia have also been reported, and it is plausible that strict inspections and fumigation policies on arrival played a role in preventing the establishment of these mosquitoes.

\section{How can we prepare for the unexpected?}

As Tatem remarked: 'There is no room for complacency because, where quarantine services must succeed every time, disease vectors need to succeed only once to establish new bridgeheads from which to invade new regions or continents' (75).

Surprise invasions will inevitably take place. Recent flareups of surra in Europe may serve as an example to show how decision-makers may have to respond to the unexpected on an ad hoc basis when introduction is a fact and establishment a serious risk. Surra, caused by Trypanosoma evansi, has never been regarded as an important candidate for dissemination into northern latitudes. However, several recent events call for a revision of this assumption. An outbreak of surra in France was reported in October 2006, on a farm which had, three months earlier, imported five camels from the Canary Islands, where T. evansi is known to be endemic. The supplier prepared camels for circus acts and entertainment parks and had imported animals from Mauritania, where T. evansi is also known to be endemic (25). After one imported camel died and parasites were detected, further investigations revealed trypanosomes in the blood of five more camels, two imported and three locally bred (24). Thus, secondary transmission had apparently taken place on the farm, probably by mechanical vectors (tabanids and Stomoxys calcitrans).

Likewise, camels from the same farm on the Canary Islands were exported to mainland Spain, again followed by an outbreak of surra (74), affecting, rather unexpectedly, nine camels, one horse and one donkey, suggesting again secondary transmission by haematophagous insects feeding on multiple host species.

These two outbreaks suggest that trade- and transportation-driven invasions can only be prevented through sound risk analysis, adequate precautionary measures in the country of origin, intensive surveillance and interception, including within areas covered by free trade agreements (71). The surra outbreaks also highlight the need for countries to be able to adjust regulation swiftly. In this case, surra was rapidly moved from the equine to the multi-species section of the World Organisation for Animal Health (OIE) list of notifiable diseases (37).

In Europe alone, it has been argued that no fewer than 12 arboviruses may have the potential to become established:

- Rift Valley fever

- Saint Louis encephalitis

- California encephalitis

- dengue fever

- Japanese encephalitis

- Kyasanur forest disease and Alkhurma virus

- eastern, western and Venezuelan equine encephalitis

- Ross River virus

- Colorado tick fever.

At least two bacteria are also considered potential invaders, one being the genus Rickettsia, the agent of human monocytic ehrlichiosis, and the other Yersinia spp. circulating in rodents (and the agent of bubonic and 
pneumonic plague in humans). The main potential vectors involved in these possible invasions are ticks and Aedes and Culex mosquitoes (78). The impact of Saint Louis encephalitis introduced into the Old World would probably be similar to that of West Nile fever introduction into the Western Hemisphere (60).

Given these risks, the question arises as to why arthropod vectors receive so little attention in current veterinary legislation, with the main focus being on microbial risks from trade and the transportation of live animals and their products. Unexpected introductions of both infected vectors and vertebrate hosts pose a threat of growing importance, requiring customisation of the early warning and vigilance systems already in place. The alert system should reflect the list of pathogens likely to be introduced, whether by trade or by natural means (e.g. bird migration). Early detection points should be identified, with demarcation of habitats that would support the new establishment of a disease and/or its arthropod vector. Early detection strategies should be detailed, describing the best available tools for monitoring, case definitions, sentinel species, etc., based on our knowledge of disease ecology. The cost-effectiveness of these measures can hardly be questioned.

\title{
Un aperçu de l'évolution de la distribution des maladies à transmission vectorielle : les échanges internationaux contribuent-ils à leur propagation?
}

\author{
S. de La Rocque, T. Balenghien, L. Halos, K. Dietze, F. Claes, G. Ferrari, \\ V. Guberti \& J. Slingenbergh
}

\section{Résumé}

Il est difficile de déterminer spécifiquement la part des échanges commerciaux dans l'extension observée de certaines maladies, car de multiples facteurs liés à la transformation des habitats et des interfaces entre les vecteurs et les hôtes sont à considérer. De fait, si les opportunités d'introduction de pathogènes par des animaux infectés, par des produits d'origine animale ou par des arthropodes vecteurs sont probablement fréquentes, l'installation d'un système vectoriel dans une zone vierge reste exceptionnelle.

Sur la base d'exemples avérés, les spécificités écologiques et épidémiologiques de quelques maladies vectorielles dont l'extension a été ou pourrait être modifiée par les échanges commerciaux sont revues ici. Sont également plus finement analysés les risques liés à certains flux commerciaux de bétail, et les risques associés à des extensions récentes de populations vectorielles. Finalement, l'enjeu de la surveillance et de la régulation sanitaire des échanges est rappelé, en insistant sur la nécessité de mieux appréhender les populations vectorielles et de se préparer aux défis de situations parfois très imprévisibles qui nécessitent une grande réactivité, y compris dans les aspects réglementaires.

\section{Mots-clés}

Animal - Commerce international - Épidémiologie - Maladie à transmission vectorielle - Produit d'origine animale - Propagation - Risque. 


\title{
Repaso de las tendencias en la distribución de enfermedades transmitidas por vectores. ¿Contribuye el comercio internacional a propagarlas?
}

\author{
S. de La Rocque, T. Balenghien, L. Halos, K. Dietze, F. Claes, G. Ferrari, \\ V. Guberti \& J. Slingenbergh
}

\section{Resumen}

Dada la multitud de factores que inciden en la transformación de los hábitat y las interfaces entre vectores y hospedadores, resulta difícil determinar el papel que ha desempeñado el comercio internacional en la expansión de enfermedades transmitidas por vectores.

Es probable que la introducción de patógenos a través del comercio de animales vivos o productos de origen animal, así como la llegada de artrópodos que ejercen de vectores, sean hechos bastante frecuentes, aunque el establecimiento de un sistema de transmisión eficiente, capaz de dar lugar a un brote infeccioso, sigue revistiendo carácter excepcional.

Basándose en ejemplos bien descritos, los autores pasan revista a las características ecológicas y epidemiológicas de enfermedades transmitidas por vectores que quizá se hayan visto influidas por el comercio internacional en su propagación y en el cambio de sus áreas de distribución. Además, presentan un detallado análisis de los riesgos ligados a determinadas rutas comerciales y de recientes episodios de expansión de las poblaciones de vectores. Por último subrayan la importancia, y también las dificultades, de la reglamentación y la vigilancia preventivas, y recalcan la necesidad de vigilar más eficazmente las poblaciones de vectores y de prepararse para afrontar episodios epidémicos impredecibles, lo que exigirá rapidez de reacción, en el terreno reglamentario inclusive.

\section{Palabras clave}

Animal - Comercio - Enfermedad transmitida por vector - Epidemiología - Producto de origen animal - Propagación - Riesgo.

\section{References}

1. Abdel-Wahab K.S.E., El Baz L.M., El Tayed E.M., Omar H., Ossman M.A.M. \& Yasin W. (1978). - Rift Valley fever virus infections in Egypt: pathological and virological findings in man. Trans. roy. Soc. trop. Med. Hyg., 72 (4), 392-396.

2. Abdo-Salem S., Gerbier G., Bonnet P., Al-Qadasi M., Tran A., Thiry E., Al-Eryni G. \& Roger F. (2006). - Descriptive and spatial epidemiology of Rift Valley fever outbreak in Yemen 2000-2001. Ann. N.Y. Acad. Sci., 1081, 240-242.

3. Angelini R., Finarelli A.C., Angelini P., Po C., Petropulacos K., Silvi G., Macini P., Fortuna C., Venturi G., Magurano F., Fiorentini C., Marchi A., Benedetti E., Bucci P., Boros S., Romi R., Majori G., Ciufolini M.G., Nicoletti L., Rezza G. \& Cassone A. (2007). - Chikungunya in north-eastern Italy: a summing up of the outbreak. Eurosurveillance, 12 (47), 3313. Available at: www.eurosurveillance.org/ViewArticle. aspx?ArticleId=3313 (accessed on 17 January 2011).
4. Aranda C., Eritja R. \& Roiz D. (2006). - First record and establishment of the mosquito Aedes albopictus in Spain. Med. vet. Entomol., 20 (1), 150-152.

5. Balenghien T., Fouque F., Sabatier P. \& Bicout D. (2006). Horse-, bird-, and human-seeking behavior and seasonal abundance of mosquitoes in a West Nile virus focus of southern France. J. med. Entomol., 43 (5), 936-946.

6. Barnard B.J., Bengis R., Keet D. \& Dekker E.H. (1994). Epidemiology of African horsesickness: duration of viraemia in zebra (Equus burchelli). Onderstepoort J. vet. Res., 61 (4), 391-393.

7. Barré N. \& Uilenberg G. (2010). - Biology of ticks. In Infectious and parasitic diseases of livestock (P.C. Lefévre, J. Blancou, R. Chermette \& G. Uilenberg, eds). Lavoisier, Paris, 107-125.

8. Beuret M., Michel S. \& Woods P. (2008). - La Chinafrique: Pékin à la conquête du continent noir. Grasset \& Fasquelle, Paris. 
9. Blancou J. \& Chillaud T. (2003). - Maladies transmissibles des animaux et commerce international. In Principales maladies infectieuses et parasitaires du bétail (P.C. Lefévre, J. Blancou \& R. Chermette, eds), Vol. 1. Lavoisier, Paris, 23-32.

10. Boinas F., Calistria P., Domingo M., Martínez-Avilés M., Martínez-López B., Rodríguez-Sánchez B. \& SánchezVizcaíno J.M. (2009). - Scientific report on African horse sickness. European Food Safety Authority, Parma, 1-61.

11. Boorman J., Mellor P.S., Penn M. \& Jennings M. (1975). The growth of African horse-sickness virus in embryonated hen eggs and the transmission of virus by Culicoides variipennis Coquillett (Diptera, Ceratopogonidae). Arch. Virol., 47 (4), 343-349.

12. Bowen R.A., Howard T.H. \& Pickett B.W. (1985). - Seminal shedding of bluetongue virus in experimentally infected bulls. Prog. clin. biol. Res., 178, 91-96.

13. Brewer A.W. \& MacLachlan N.J. (1992). - Ultrastructural characterization of the interaction of bluetongue virus with bovine erythrocytes in vitro. Vet. Pathol., 29 (4), 356-359.

14. Chevalier V., de La Rocque S., Baldet T., Vial L. \& Roger F. (2004). - Epidemiological processes involved in the emergence of vector-borne diseases: West Nile fever, Rift Valley fever, Japanese encephalitis and Crimean-Congo haemorrhagic fever. In Emerging zoonoses and pathogens of public health concern (L.J. King, ed.). Rev. sci. tech. Off. int. Epiz., 23 (2), 535-555.

15. Coetzer J.A.W. \& Guthrie A.J. (2004). - African horse sickness. In Infectious diseases of livestock (J. Coetzer \& R. Tustin, eds), 2nd Ed. Oxford University Press, Oxford, 1231-1247.

16. Costard S., Wieland B., de Glanville W., Jori F., Rowlands R., Vosloo W., Roger F., Pfeiffer D.U. \& Dixon L.K. (2009). - African swine fever: how can global spread be prevented? Philos. Trans. roy. Soc. Lond., B, biol. Sci., 364 (1530), 2683-2696.

17. Cuisance D. \& Rioux J.A. (2004). - Current status of medical and veterinary entomology in France: endangered discipline or promising science? Comp. Immunol. Microbiol. infect. Dis., 27 (5), 377-392

18. Davies F.G. (1998). - Rift Valley fever and livestock trade from the Horn of Africa (Ethiopia, Somalia, Kenya). Consultant report. Food and Agriculture Organization of the United Nations, Rome, 28 pp.

19. Davies F.G. (2006). - Risk of a Rift Valley fever epidemic at the haj in Mecca, Saudi Arabia. In Biological disasters of animal origin. The role and preparedness of veterinary and public health services (M. Hugh-Jones, ed.). Rev. sci. tech. Off. int. Epiz., 25 (1), 137-147.

20. Davies F.G. \& Nunn M.J. (1998). - Risk of Rift Valley fever from livestock imported into the Kingdom of Saudi Arabia from the Horn of Africa. Consultant report. Food and Agriculture Organization of the United Nations, Rome, $17 \mathrm{pp}$.
21. Davies F.G., Linthicum K.J. \& James A.D. (1985). - Rainfall and epizootic Rift Valley fever. Bull. WHO, 63 (5), 941-943.

22. De La Rocque S., Rioux J.A. \& Slingenbergh J. (2008). Climate change: effects on animal disease systems and implications for surveillance and control. In Climate change: the impact on the epidemiology and control of animal diseases (S. de La Rocque, S. Morand \& G. Hendrickx, eds). Rev. sci. tech. Off. int. Epiz., 27 (1), 339-351.

23. De Liberato C., Scavia G., Lorenzetti R., Scaramozzino P., Amaddeo D., Cardeti G., Scicluna M., Ferrari G. \& Autorino G.L. (2005). - Identification of Culicoides obsoletus (Diptera: Ceratopogonidae) as a vector of bluetongue virus in central Italy. Vet. Rec., 156 (10), 301-304.

24. Desquesnes M., Bossard G., Patrel D., Herder S., Patout O., Lepetitcolin E., Thevenon S., Berthier D., Pavlovic D., Brugidou R., Jacquiet P., Schelcher F, Faye B., Touratier L. \& Cuny G. (2008). - First outbreak of Trypanosoma evansi in camels in metropolitan France. Vet. Rec., 162 (23), 750-752.

25. Dia M.L., Diop C., Aminetou M., Jacquiet P. \& Thiam A. (1997). - Some factors affecting the prevalence of Trypanosoma evansi in camels in Mauritania. Vet. Parasitol., $72(2), 111-120$

26. Du Toit R.M. (1944). - The transmission of bluetongue and horsesickness by Culicoides. Onderstepoort J. vet. Res., 19, 7-16.

27. Enserink M. (2010). - Infectious diseases. Yellow fever mosquito shows up in northern Europe. Science, 329 (5993), 736.

28. European Food Safety Authority (EFSA) (2005). - Opinion of the Scientific Panel on Animal Health and Welfare on a request from the Commission related to 'The risk of a Rift Valley fever incursion and its persistence within the community'. EFSA J., 3 (10), 1-128. Available at: www.efsa. europa.eu/fr/efsajournal/doc/238.pdf (accessed on 27 January 2011).

29. European Food Safety Authority (EFSA) (2007). Bluetongue serotype 8 epidemic bulletin by EFSA Epidemiology Working Group. Available at: www.efsa. europa.eu/en/in_focus/bluetongue/outbreak_overview.html (updated on 6 February 2007).

30. European Food Safety Authority (EFSA) (2008). - Opinion of the Scientific Panel on Animal Health and Welfare on a request from the Commission on bluetongue. Doi: 10.2903/j. efsa.2008.735. EFSA J., 735, 1-69.

31. European Food Safety Authority (EFSA) (2010). - EFSA Panel on Animal Health and Welfare; scientific opinion on African swine fever. EFSA J., 8 (3), 149 pp.

32. Fontenille D., Lagneau C., Lecollinet S., Lefait-Robin R., Setbon M., Tirel B. \& Yebakima A. (2009). La lutte antivectorielle en France. Institut de recherche pour le développement, Marseilles, 533 pp. 
33. Food and Agriculture Organization of the United Nations (FAO) (2008). - Emergency Prevention Programme for Transboundary Animal Diseases (EMPRES) Watch: African swine fever in the Caucasus. FAO, Rome. Available at: ftp://ftp.fao.org/docrep/fao/011/aj214e/aj214e00.pdf (accessed on 10 February 2011).

34. Food and Agriculture Organization of the United Nations (FAO) (2009). - Emergency Prevention Programme for Transboundary Animal Diseases (EMPRES) Watch: African swine fever spread in the Russian Federation and the risk for the region. FAO, Rome. Available at: ftp://ftp.fao. org/docrep/fao/012/ak718e/ak718e00.pdf (accessed on 10 February 2011).

35. Gad A.M., Feinsod F.M., Allam I.H., Eisa M., Hassan A.N., Soliman B.A., El Said S. \& Saah A.J. (1986). A possible route for the introduction of Rift Valley fever virus into Egypt during 1977. J. trop. Med. Hyg., 89 (5), 233-236.

36. Gubler D.J. (2009). - Vector-borne diseases. In Veterinary education for global animal and public health (D.A. Walsh, ed.). Rev. sci. tech. Off. int. Epiz., 28 (2), 583-588.

37. Gutierrez C., Desquesnes M., Touratier L. \& Büscher P. (2010). - Trypanosoma evansi: recent outbreaks in Europe. Vet. Parasitol., 174 (1-2), 26-29. E-pub.: 20 August 2010.

38. Hayes E.B., Komar N., Nasci R.S., Montgomery S.P., O'Leary D.R. \& Campbell G.L. (2005). - Epidemiology and transmission dynamics of West Nile virus disease. Emerg. infect. Dis., 11 (8), 1167-1173.

39. Hays J.N. (2005). - Second plague pandemic 1346-1844. In Epidemics and pandemics: their impacts on human history. Library of Congress, Washington, DC, 41-69.

40. Hendrickx G., Gilbert M., Staubach C., Elbers A., Mintiens K., Gerbier G. \& Ducheyne E. (2008). A wind density model to quantify the airborne spread of Culicoides species during north-western Europe bluetongue epidemic, 2006. Prev. vet. Med., 87 (1-2), 162-181. E-pub.: 17 July 2008.

41. Kirkland P.D. \& Hawkes R.A. (2004). - A comparison of laboratory and 'wild' strains of bluetongue virus - is there a difference and does it matter? Vet. ital., 40 (4), 448-455.

42. Lammie P.J., Lindo J.F., Evan Secor W., Vasquez J., Ault S.K. \& Eberhard M.L. (2007). - Eliminating lymphatic filariasis, onchocerciasis, and schistosomiasis from the Americas: breaking a historical legacy of slavery. Doi:10.1371/ journal.pntd.0000071. PLoS negl. trop. Dis., 1 (2), e71.

43. Lanciotti R.S., Roehrig J.T., Deubel V., Smith J., Parker M., Steele K., Crise B., Volpe K.E., Crabtree M.B., Scherret J.H., Hall R.A., MacKenzie J.S., Cropp C.B., Panigrahy B., Ostlund E., Schmitt B., Malkinson M., Banet C., Weissman J., Komar N., Savage H.M., Stone W., McNamara T. \& Gubler D.J. (1999). - Origin of the West Nile virus responsible for an outbreak of encephalitis in the northeastern United States. Science, 286 (5448), 2333-2337.
44. Lubroth J. (1988). - African horse sickness and the epizootic in Spain. Equine Pract., 10, 26-33.

45. Lyra T.M.P. (2006). - The eradication of African swine fever in Brazil, 1978-1984. In Biological disasters of animal origin. The role and preparedness of veterinary and public health services (M. Hugh-Jones, ed.). Rev. sci. tech. Off. int. Epiz., 25 (1), 93-103.

46. McIntosh B.M., Jupp P.G., dos Santos I. \& Barnard B.J. (1980). - Vector studies on Rift Valley fever virus in South Africa. S. Afr. med. J., 58 (3), 127-132.

47. McMichael A.J. (2004). - Environmental and social influences on emerging infectious diseases: past, present and future. Philos. Trans. roy. Soc. Lond., B, biol. Sci., 359 (1447), 1049-1058.

48. Malkinson M., Banet C., Weisman Y., Pokamunski S., King R., Drouet M.T. \& Deubel V. (2002). - Introduction of West Nile virus in the Middle East by migrating white storks. Emerg. infect. Dis., 8 (4), 392-397.

49. Meegan J.M. (1979). - The Rift Valley fever epizootic in Egypt 1977-78. 1. Description of the epizootic and virological studies. Trans. roy. Soc. trop. Med. Hyg., 73 (6), 618-623.

50. Meegan J.M. \& Bailey C.L. (1988). - Rift Valley fever. In Arboviruses: epidemiology and ecology (T.P. Monath, ed.). CRC Press, Boca Raton, Florida, 51-76.

51. Meiswinkel R. \& Paweska J.T. (2003). - Evidence for a new field Culicoides vector of African horse sickness in South Africa. Prev. vet. Med., 60 (3), 243-253.

52. Mellor P.S., Carpenter S., Harrup L., Baylis M. \& Mertens P.P. (2008). - Bluetongue in Europe and the Mediterranean Basin: history of occurrence prior to 2006. Prev. vet. Med., 87 (1-2), 4-20. E-pub.: 10 July 2008

53. Mintiens K., Méroc E., Mellor P.S., Staubach C., Gerbier G., Elbers A.R.S., Hendrickx G. \& De Clercq K. (2008). Possible routes of introduction of bluetongue virus serotype 8 into the epicentre of the 2006 epidemic in north-western Europe. Prev. vet. Med., 87 (1-2), 131-144. E-pub.: 29 July 2008.

54. Morel P.C. (2000). - Maladies du bétail transmises par les tiques. In Précis de parasitologie vétérinaire tropicale (C. Chartier, J. Itard, P.M. Troncy \& P.C. Morel). Editions Médicales Internationales, Coll. Universités Francophones, Paris, 451-768

55. Moutou F. (2007). - La vengeance de la civette masquée. SRAS, grippe aviaire ... d'où viennent les nouvelles épidémies ? Le Pommier, Paris, 332 pp.

56. Parmakelis A., Russello M.A., Caccone A., Marcondes C.B., Costa J., Forattini O.P., Sallum M.A., Wilkerson R.C. \& Powell J.R. (2008). - Historical analysis of a near disaster: Anopheles gambiae in Brazil. Am. J. trop. Med. Hyg., 78 (1), 176-178. 
57. Ponçon N., Balenghien T., Toty C., Ferré J.B., Thomas C., Dervieux A., L'Ambert G., Schaffner F, Bardin O. \& Fontenille D. (2007). - Effects of local anthropogenic changes on potential malaria vector Anopheles hyrcanus and West Nile virus vector Culex modestus, Camargue, France. Emerg. infect. Dis., 13 (12), 1810-1815. Available at: www.cdc.gov/eid/content/13/12/1810.htm (accessed on 10 February 2011).

58. Reiter P. (1998). - Aedes albopictus and the world trade in used tires, 1988-1995: the shape of things to come? J. Am. Mosq. Control Assoc., 14 (1), 83-94

59. Reiter P. (2008). - Climate change and mosquito-borne diseases: knowing the horse before hitching the cart. In Climate change: impact on the epidemiology and control of animal diseases (S. de La Rocque, S. Morand \& G. Hendrickx, eds). Rev. sci. tech. Off. int. Epiz., 27 (2), 383-398

60. Reiter P. (2010). - West Nile virus in Europe: understanding the present to gauge the future. Eurosurveillance, 15 (10), 1-7.

61. Reiter P. (2010). - Yellow fever and dengue: a threat to Europe? Eurosurveillance, 2015 (10). Available at: www. eurosurveillance.org/ViewArticle.aspx?ArticleId= 19509 (accessed on 27 January 2011)

62. Rodhain F. (2001). - La notion d'émergence dans le domaine des maladies à vecteurs. Assoc. anc. Él. Inst. Pasteur, 166, 1-7.

63. Rodhain F. \& Saluzzo J.F. (2005). - Grippe, rage, méningites, SRAS... Le mystère des épidémies. Pasteur, Paris, 409 pp.

64. Rodriguez M., Hooghuis H. \& Castano M. (1992). - African horse sickness in Spain. Vet. Microbiol., 33 (1-4), 129-142.

65. Sánchez-Botija A. (1963). - Reservorios del virus de la peste porcina Africana. Investigacion del virus la PPA en los artrópodos mediante la prueba de la hemoadsorción. Bull. Off. int. Epiz., 60, 895-899.

66. Schaffner F, Kaufman C., Hegglin D. \& Mathis A. (2009). The invasive mosquito Aedes japonicus in Central Europe. Med. vet. Entomol., 23 (4), 448-451.

67. Scholte E.J. \& Schaffner F. (2007). - Waiting for the tiger: establishment and spread of the Aedes albopictus mosquitoes in Europe. In Emerging pests and vector-borne diseases in Europe (W. Takken \& B.G.J. Knols, eds). Wageningen Academic Publishers, Wageningen, the Netherlands, $241-260$

68. Schwartz M. \& Rodhain F. (2008). - Des microbes ou des hommes, qui va l'emporter? Odile Jacob, Paris, 339 pp.

69. Sellers R.F. \& Taylor W.P. (1980). - Epidemiology of bluetongue and the import and export of livestock, semen and embryos. Bull. Off. int. Epiz., 92, 587-592.

70. Sellers R.F., Pedgley D.E. \& Tucker M.R. (1982). - Rift Valley fever, Egypt 1977: disease spread by windborne insect vectors? Vet. Rec., 110 (4), 73-77.
71. Sheesley D.J. \& Greifer J.K. (1996). - Implication of international trade agreements for global animal health. In Vector-borne pathogens: international trade and tropical animal diseases. Ann. N.Y. Acad. Sci., 791, 296-302

72. Shoemaker T., Boulianne C., Vincent M.J., Pezzanite L., AlQahtani M.M., Al-Mazrou Y., Khan A.S., Rollin P.E., Swanepoel R., Ksiazek T.G. \& Nichol S.T. (2002). - Genetic analysis of viruses associated with emergence of Rift Valley fever in Saudi Arabia and Yemen, 2000-2001. Emerg. infect. Dis., 8 (12), 1415-1420.

73. Swanepoel R. \& Coetzer J.A.W. (2004). - Rift Valley fever. In Infectious diseases of livestock (J. Coetzer \& R. Tustin, eds), 2nd Ed. Oxford University Press, Oxford, 1037-1070.

74. Tamarit A., Gutierrez C., Arroyo R., Jimenez V., Zagalá G., Bosch I., Sirvent J., Alberola J., Alonso I. \& Caballero C. (2010). - Trypanosoma evansi infection in mainland Spain. Vet. Parasitol., 167 (1), 74-76.

75. Tatem A.J., Hay S. \& Rogers D.J. (2006). - Global traffic and disease vector dispersal. Proc. natl Acad. Sci. USA, 103 (16), 6242-6247. E-pub.: 10 April 2006.

76. Thiry E., Saegerman C., Guyot H., Kirten P., Losson B., Rollin F., Bodmer M., Czaplicki G., Toussaint J.F., De Clercq K., Dochy J.M., Dufey J., Gilleman J.L. \& Messeman K. (2006). - Bluetongue in northern Europe. Vet. Rec. 159 (10), 327.

77. Uilenbergh G. (1992). - International transport of tick-borne diseases in animals: example of heartwater in the western hemisphere. In Proc. 19th International Congress on Entomology, 28 June - 4 July, Beijing, 492 pp.

78. Van der Weijden W.J., Marcelis R.A.L. \& Reinhold W. (2007). - Invasion of vector-borne diseases driven by transportation and climate change. In Emerging pests and vector-borne diseases in Europe (W. Takken \& B.G.J. Knols, eds). Wageningen Academic Publishers, Wageningen, the Netherlands, 439-463.

79. Versteirt V., Schaffner F., Garros C., Dekoninck W., Coosemans M.H. \& Van Bortel W. (2009). - Introduction and establishment of the exotic mosquito species Aedes japonicus japonicus (Diptera: Culicidae) in Belgium. J. med. Entomol., 46 (6), 1464-1467.

80. Zientara S. (2003). - La peste équine. In Principales maladies infectieuses et parasitaires du bétail (P.C. Lefévre, J. Blancou \& R. Chermette, eds), Vol 1. Lavoisier, Paris, 687-703. 